\title{
Biochar from different residues on soil properties and common bean production
}

\author{
Isley Cristiellem Bicalho da Silva, Josiana Jussara Nazaré Basílio, Luiz Arnaldo Fernandes* , Fernando Colen, Regynaldo Arruda \\ Sampaio, Leidivan Almeida Frazão
}

Federal University of Minas Gerais/Agricultural Science Institute, Av. Universitária, 1000 - 39404-547 - Montes

Claros, MG - Brazil.

*Corresponding author <luizmcmg@gmail.com>

Edited by: Leônidas Carrijo Azevedo Melo

Received June 15, 2016

Accepted September 27, 2016
ABSTRACT: The production of biochar from organic residues promises to be an interesting strategy for the management of organic waste. To assess the effect of biochar on soil properties and the production and nutrition of common bean (Phaseolus vulgaris L.), three simultaneous experiments were conducted in a greenhouse with different biochar from organic residues (rice husk, sawdust, and sorghum silage) used as filtration material for swine biofertilizer. In each experiment the treatments consisted of five different biochar concentrations $(0,25,50$, 75 and $100 \mathrm{~L} \mathrm{~m}^{-3}$ ), arranged in a completely randomized design, with four repetitions. In the experiments, the use of biochar increased soil $\mathrm{pH}$, cation exchange capacity, nutrient availability in the soil, and nutrient accumulation in grains. The biochar concentrations corresponding to the maximum production of grain dry matter of bean plants were 100,68 , and $71 \mathrm{~L} \mathrm{~m}^{-3}$ for biochar from rice husk filter (BRHF), biochar from sawdust filter (BSF), and biochar from sorghum silage filter (BSSF), respectively.

Keywords: Phaseolus vulgaris L., agricultural residues, biochar, soil fertility

\section{Introduction}

The use of organic residues as filtration materials is an efficient and inexpensive option for the primary treatment of wastewaters. However, as the filtration media retains liquid impurities, the filtration rate decreases over time thereby making total or partial replacement of the filtration material at defined intervals a necessity. These replacements lead to the formation of large furrows of residues, which can be used directly as organic fertilizers. Alternatively, this residue could undergo a process of pyrolysis under controlled conditions of temperature and oxygen to produce a material called biochar (Mukherjee and Lal, 2016).

The term biochar refers to a solid carbon-rich material of fine texture, with high specific surface area, which is obtained from the thermochemical transformation of biomass in a low oxygen environment (Kookana et al., 2011). The biochar production from materials discarded from filtration is interesting for several reasons. First, the production of biochar facilitates the recycling of large amounts of residues (Abdelhafez et al., 2014), which reduces environmental waste (Ahmad et al., 2014). Second, carbon in biochar is more resistant to chemical and biological decomposition than the material in natura, which results in increased soil carbon stock, and mitigation of $\mathrm{CO}_{2}$ emissions. Finally, biochar could be used as a soil conditioner to increase crop yield (Mukherjee and Lal, 2016).

Although environmental and agricultural benefits are well described in various studies (Albuquerque et al., 2014; Chan et al., 2007; Mukherjee and Lal, 2016; Uzoma et al., 2011), there is a great variability in plant responses to the application of biochar to soil, depending on the diversity of materials used and pyrolysis conditions.
Therefore, the aim of the present study was to assess the effect of biochar on soil properties and the production and nutrition of common bean (Phaseolus vulgaris L.).

\section{Materials and Methods}

\section{Preparation and characterization of biochar}

The biochar used in the present study was produced from material obtained from three different organic filters, used in the filtration of swine biofertilizer from an anaerobic biodigestor.

After filling the filters with the biofertilizer solids, the filtration media of rice husk, sawdust, and sorghum silage were removed and air-dried. These materials were then charred using a traditional carbonizer. During the charring process, the temperature varied between $385^{\circ} \mathrm{C}$ and $430{ }^{\circ} \mathrm{C}$ and the total duration of the process varied between 2.3 and $3.2 \mathrm{~h}$.

The biochar that resulted from charred filters was designated as biochar from rice husk (BRHF), biochar from sawdust filter (BSF), and biochar from sorghum silage filter (BSSF). The yield of each biochar was determined using the following equation: Biochar yield = biochar mass/filtration material mass.

The biochar was ground into particles $1<0.5$ $\mathrm{mm}$ ) before applying to the soil and prior to sampling for characterization. Biochar chemical characterization (Table 1) was performed according to the official method proposed by the Brazilian Ministry of Agriculture and Supply (MAPA, 2015) for organic fertilizers.

\section{Greenhouse experiments}

Three experiments were conducted simultaneously in a greenhouse between Feb and Apr 2015. Each experiment comprised the application of one biochar type 
Table 1 - Chemical and physical characterization of biochar.

\begin{tabular}{lccc}
\hline Characteristic & BRHF & BSF & BSSF \\
\hline Yield (\%) & 33 & 45 & 38 \\
Maximum Temperature $\left({ }^{\circ} \mathrm{C}\right)$ & 430 & 385 & 385 \\
Carbonization time (h) & 2.3 & 3.0 & 3.2 \\
$\mathrm{pH}$ & 6.8 & 7.1 & 7.2 \\
Electric conductivity $\left(\mathrm{mS} \mathrm{cm}^{-1}\right)$ & 121.8 & 69.8 & 97 \\
Density $\left(\mathrm{kg} \mathrm{m}^{-3}\right)$ & 370 & 510 & 540 \\
Ashes $(\%)$ & 29 & 15 & 40 \\
Organic carbon $\left(\mathrm{g} \mathrm{kg}^{-1}\right)$ & 14.4 & 430.4 & 332.4 \\
$\mathrm{~N}\left(\mathrm{~g} \mathrm{~kg}^{-1}\right)$ & 16.5 & 12.4 & 22.8 \\
$\mathrm{P}\left(\mathrm{g} \mathrm{kg}^{-1}\right)$ & 34 & 16.7 & 29.6 \\
$\mathrm{~K}\left(\mathrm{~g} \mathrm{~kg}^{-1}\right)$ & 6.7 & 3.5 & 4.75 \\
Ca $\left(\mathrm{g} \mathrm{kg}^{-1}\right)$ & 27.3 & 17.8 & 24.44 \\
$\mathrm{Mg} \mathrm{(g} \mathrm{kg}$ & \\
$\mathrm{S}\left(\mathrm{g} \mathrm{kg}^{-1}\right)$ & 8 & 3.9 & 7.1 \\
\hline
\end{tabular}

$\mathrm{BRHF}=$ biochar from rice husk; $\mathrm{BSF}=$ biochar from sawdust filter; $\mathrm{BSSF}=$ biochar from sorghum silage filter.

(BRHF, BSF, or BSSF). The treatments consisted of five different biochar concentrations $(0,25,50,75$ and $10 \mathrm{~L}$ $\left.\mathrm{m}^{-3}\right)$, arranged in a completely randomized design, with four repetitions.

The surface layer (0 to $20 \mathrm{~cm}$ ) of an Oxisol (Typic Ustox) (Soil Survey Staff, 1998) was collected from an area of native vegetation (geographic coordinates: $16^{\circ} 54^{\prime} 14.99^{\prime \prime} \mathrm{S}$ and $43^{\circ} 57^{\prime} 41.28^{\prime \prime} \mathrm{W}$; altitude: $600 \mathrm{~m}$ above sea level), municipality of Montes Claros, state of Minas Gerais. The physical and chemical soil properties were determined according to Claessen (1997): sand = $780 \mathrm{~g} \mathrm{~kg}^{-1}$; silt $=100 \mathrm{~g} \mathrm{~kg}^{-1}$; clay $=120 \mathrm{~g} \mathrm{~kg}^{-1} ; \mathrm{pH}\left(\mathrm{H}_{2} \mathrm{O}\right)$ $=5.2 ;$ available phosphorus (resin method) $=18.01 \mathrm{mg}$ $\mathrm{dm}^{-3} ;$ potassium $=0.89 \mathrm{mmol}_{\mathrm{c}} \mathrm{dm}^{-3} ;$ calcium $=5.0$ $\mathrm{mmol}_{\mathrm{c}} \mathrm{dm}^{-3}$; magnesium $=2.0 \mathrm{mmol}_{\mathrm{c}} \mathrm{dm}^{-3}$; aluminum $=2.4 \mathrm{mmol}_{\mathrm{c}} \mathrm{dm}^{-3}$; base saturation $=24 \%$; effective cation exchange capacity $\mathrm{pH} 7.0=32.5 \mathrm{mmol}_{\mathrm{c}} \mathrm{dm}^{-3}$; soil organic carbon $=11.6 \mathrm{~g} \mathrm{~kg}^{-1}$.

The soil was sifted $(<4 \mathrm{~mm})$ and placed in 4 $\mathrm{L}$ plastic pots. The soil in each pot was homogenized with $5 \mathrm{~g}$ of simple superphosphate $\left(22 \%\right.$ of $\left.\mathrm{P}_{2} \mathrm{O}_{5}\right)$. The amounts of nutrients supplied by the biochar application are shown in Table 2.

Ten bean seeds (Phaseolus vulgaris L. cultivar BRSMG Talismã) were sown in each pot. Thinning was performed after seedling emergence and two plants were kept per pot. The pots were regularly irrigated with distilled water and moisture was kept near field capacity throughout the experimental period. Water availability in the soil was monitored daily by weighing the pots, and water were replaced when necessary.

Four top-dressing fertilizations were performed during the experimental period at 14,21, 28, and 35 days after planting. In the two first fertilizations, each pot received $240 \mathrm{mg} \mathrm{dm}^{-3}$ of $\mathrm{MgNO}_{3}$ and $250 \mathrm{mg} \mathrm{dm}^{-3}$ of $\mathrm{KNO}_{3}$. On the last two fertilizations, $100 \mathrm{mg} \mathrm{dm}^{-3}$ of urea was applied per pot, defined according to the development of the plants.
Table 2 - Amounts of added nutrients to the soil by different biochar.

\begin{tabular}{lcrrrrrrr}
\hline Level & \multicolumn{8}{c}{ Nutrients $\left(\mathrm{mg} \mathrm{dm}^{-3}\right)$} \\
\cline { 2 - 9 }$\left(\mathrm{L} \mathrm{m}^{-3}\right)$ & & \multicolumn{1}{c}{$\mathrm{C}$} & \multicolumn{1}{c}{$\mathrm{N}$} & \multicolumn{1}{c}{$\mathrm{P}$} & \multicolumn{1}{c}{$\mathrm{K}$} & \multicolumn{1}{c}{$\mathrm{Ca}$} & $\mathrm{Mg}$ & \multicolumn{1}{c}{$\mathrm{S}$} \\
\hline \multirow{4}{*}{25} & BRHF & 2908.2 & 152.6 & 314.5 & 61.9 & 252.5 & 74.0 & 18.5 \\
& BSF & 5487.6 & 158.1 & 212.93 & 44.6 & 226.9 & 49.7 & 16.6 \\
& BSSF & 4487.4 & 307.8 & 399.6 & 64.1 & 329.9 & 95.9 & 20.3 \\
\cline { 2 - 9 } 50 & BRHF & 5816.4 & 305.3 & 629.0 & 123.9 & 505.1 & 148.0 & 37.0 \\
& BSF & 10975.2 & 316.2 & 425.9 & 89.2 & 453.9 & 99.5 & 33.2 \\
& BSSF & 8974.8 & 615.6 & 799.2 & 128.3 & 659.9 & 191.7 & 40.5 \\
\cline { 2 - 9 } 75 & BRHF & 8723.6 & 457.9 & 943.5 & 185.9 & 757.6 & 222.0 & 55.5 \\
& BSF & 16462.8 & 474.3 & 638.8 & 133.9 & 680.9 & 149.2 & 49.7 \\
& BSSF & 13462.2 & 923.4 & 1198.8 & 192.4 & 989.8 & 287.6 & 60.8 \\
\cline { 2 - 9 } 100 & BRHF & 11632.8 & 610.5 & 1258.0 & 247.9 & 1010.1 & 296.0 & 74.0 \\
& BSF & 21950.4 & 632.4 & 851.7 & 178.5 & 907.8 & 198.9 & 66.3 \\
& BSSF & 17949.6 & 1231.2 & 1598.4 & 256.5 & 1319.8 & 383.4 & 81.0 \\
\hline
\end{tabular}

$\overline{\mathrm{BRHF}}=$ biochar from rice husk; $\mathrm{BSF}=$ biochar from sawdust filter; $\mathrm{BSSF}=$ biochar from sorghum silage filter.

\section{Experiment assessment}

In the physiological maturation of the bean plant, two months after sowing, the grains were collected and dried in a forced-air oven at $60{ }^{\circ} \mathrm{C}$, until a steady mass was reached to determine the grain dry matter. Then, the grains were ground and $\mathrm{N}, \mathrm{P}, \mathrm{K}, \mathrm{S}, \mathrm{Ca}$, and $\mathrm{Mg}$ contents were determined according to the method described by Maathuis (2013). The accumulation of nutrients in the grains was estimated by multiplying nutrient content by dry grain weight. Soil chemical properties were determined in samples from each pot according to Claessen (1997).

The data were subjected to the analysis of variance $(p<0.05)$ and regression equations were obtained for the variables under study.

\section{Results and Discussion}

\section{Soil properties}

Soil $\mathrm{pH}$ values increased linearly after the addition of the biochar produced from filtration of waste materials. At the highest dose (10 $\mathrm{L} \mathrm{m}^{-3}$ of soil volume), BRHF, $\mathrm{BSF}$, and BSSF increased the soil $\mathrm{pH}$ by $0.76,1.17$, and 1.68 units, respectively (Table 3). Therefore, biochar acted on soil as an acidity corrector. This increase in soil $\mathrm{pH}$ was also observed in other studies (Albuquerque et al., 2014; Chan et al., 2007; Yuan and $\mathrm{Xu}, 2012$ ) and is regarded as a positive biochar effect, particularly in acidic soils.

In addition to the $\mathrm{pH}$ increase, exchangeable cation content $(\mathrm{K}, \mathrm{Ca}$, and $\mathrm{Mg})$ increased with biochar concentrations (Table 3), which is in line with previous studies (Chan et al., 2007; Houben et al., 2013; Rondon et al., 2007). The increase in $\mathrm{pH}$, and in exchangeable cation content, may be explained by the presence of ashes in the biochar (Table 1). Ashes are rich in oxides and hydroxides of alkali metals, which are easily dissolved and react rapidly with the soil thereby increasing the $\mathrm{pH}$ 
Table 3 - Regression equations adjusted between soil properties and biochar levels.

\begin{tabular}{|c|c|c|c|c|c|}
\hline Soil properties & Biochar & Equations & $\mathrm{R}^{2}$ & Vmax & Nmax \\
\hline & BRHF & $y=52.43+0.756^{* *} x$ & 0.98 & 6.00 & 10 \\
\hline \multirow[t]{3}{*}{$\mathrm{pH}$} & BSF & $y=50.93+1.166^{* *} x$ & 0.99 & 6.26 & 10 \\
\hline & BSSF & $y=51.73+1.676^{* *} x$ & 0.98 & 6.85 & 10 \\
\hline & BRHF & $y=204.42+71.99^{* *} x$ & 0.97 & 92.43 & 10 \\
\hline \multirow[t]{3}{*}{$P\left(\mathrm{mg} \mathrm{dm}^{-3}\right)$} & BSF & $y=199.20+65.00^{* *} x$ & 0.96 & 84.92 & 10 \\
\hline & BSSF & $y=198.38+72.72^{* *} x$ & 0.96 & 92.56 & 10 \\
\hline & BRHF & $y=295.84+15.39^{* *} x$ & 0.96 & 44.97 & 10 \\
\hline \multirow[t]{3}{*}{$\mathrm{K}\left(\mathrm{mg} \mathrm{dm}^{-3}\right)$} & BSF & $y=232.54+40.47^{* *} x$ & 0.91 & 63.72 & 10 \\
\hline & BSSF & $y=222.59+136.49^{* *} x$ & 0.98 & 158.75 & 10 \\
\hline & BRHF & $y=12.20-0.21^{* *} x+0.087^{*} x^{2}$ & 0.95 & 1.88 & 10 \\
\hline \multirow[t]{3}{*}{$\mathrm{Ca}\left(\mathrm{cmol}_{\mathrm{c}} \mathrm{dm}^{-3}\right)$} & BSF & $y=12.28-0.19^{* *} x+0.097^{*} x^{2}$ & 0.99 & 2.01 & 10 \\
\hline & BSSF & $y=11.95+0.80^{* *} x$ & 0.99 & 1.99 & 10 \\
\hline & BRHF & $y=5.93+0.07^{* *} x+0.017^{*} x^{2}$ & 0.84 & 0.83 & 10 \\
\hline \multirow[t]{3}{*}{$\mathrm{Mg}\left(\mathrm{cmol}_{\mathrm{c}} \mathrm{dm}^{-3}\right)$} & BSF & $y=5.98-0.163^{* *} x+0.05^{*} x^{2}$ & 1.00 & 0.90 & 10 \\
\hline & BSSF & $y=5.70+0.32^{* *} x$ & 0.96 & 0.89 & 10 \\
\hline & BRHF & $y=36.73-0.726^{* *} x+0.18^{*} x^{2}$ & 0.92 & 4.75 & 10 \\
\hline \multirow[t]{3}{*}{ Cation Exchange Capacity $\left(\mathrm{cmol}_{\mathrm{c}} \mathrm{dm}^{-3}\right)$} & BSF & $y=36.73+0.78^{* *} x$ & 0.92 & 4.45 & 10 \\
\hline & BSSF & $y=37.23+0.67^{\star *} x$ & 0.90 & 4.39 & 10 \\
\hline & BRHF & $y=105.80+6.42 x^{* *}$ & 0.98 & 1.70 & 10 \\
\hline \multirow[t]{2}{*}{ Soil Organic Carbon $\left(\mathrm{g} \mathrm{kg}^{-1}\right.$ ) } & BSF & $y=102.71+6.01^{* *} x$ & 0.99 & 1.63 & 10 \\
\hline & BSSF & $y=93.54+8.53^{* *} x$ & 0.94 & 1.78 & 10 \\
\hline
\end{tabular}

Vmax = maximum value of the variable response estimated by the regression equation; Nmax = concentration of biochar corresponding to the maximum value of the variable response; $\mathrm{BRHF}=$ biochar from rice husk; $\mathrm{BSF}=$ biochar from sawdust filter; $\mathrm{BSSF}=$ biochar from sorghum silage filter.

(Steenari et al., 1999) and releasing free bases, such as $\mathrm{K}, \mathrm{Ca}, \mathrm{Mg}$, and other ions into the soil solution (Glaser et al., 2002).

The available $\mathrm{P}$ content in the soil increased linearly (Table 3). This change was primarily a result of the high $\mathrm{P}$ concentration in biochar (Table 1), since $\mathrm{P}$ is only lost via volatilization at pyrolysis temperatures higher than $760{ }^{\circ} \mathrm{C}$ (Knicker, 2007).

Another possibility for increasing $\mathrm{P}$ availability was to increase the soil $\mathrm{pH}$ by applying biochar. According to Troeh and Thompson (2005), when the soil $\mathrm{pH}$ is lower than 5.7, $\mathrm{P}$ is predominantly in the form of $\mathrm{H}_{2} \mathrm{PO}_{4}{ }^{-}$ions, which frequently reacts with or is adsorbed by $\mathrm{Fe}$ or $\mathrm{Al}$ compounds to form low-solubility compounds.

In addition, Andrade et al. (2002) reported that the incorporation of organic material to the soil increases $\mathrm{P}$ availability. The negative charges in the functional groups of the organic matter compete with $\mathrm{P}$ for adsorption sites and complex $\mathrm{Fe}$ and $\mathrm{Al}$ ions thereby increasing $\mathrm{P}$ activity in the soil solution. Thus, negative electric charges in biochar are likely to have blocked the fixation sites of $\mathrm{P}$ in the soil and/or complexed with $\mathrm{Fe}$ and $\mathrm{Al}$ in the solution. Moreover, the additional $\mathrm{P}$ supplied by biochar is an important contribution because the soils in the Brazilian Cerrado are characterized by a low $\mathrm{P}$ availability to plants.

Cation exchange capacity (CEC) values increased with the concentrations of biochar in the three experiments (Table 3). These results confirm that biochar altered the density of $\mathrm{pH}$-dependent negative charges. Be- cause of the continuous oxidation of surfaces, and the adsorption of organic acids by biochar, CEC is expected to increase further with time, as observed in the study by Cheng et al. (2008). These authors reported that the incubation of a biochar during one year raised its CEC from 1.7 to $71.0 \mathrm{mmol} \mathrm{kg}^{-1}$.

The content of soil organic carbon (SOC) increased linearly with biochar concentrations (Table 3). This is probably because biochar also undergoes biodegradation, although it is considered stable in the soil system. According to Bird et al. (1999), the time required for biodegradation of soil-charred particles is related to their granulometry. These authors estimated that the half-life of particles smaller than $2 \mathrm{~mm}$ is lower than 50 years and that of particles larger than $2 \mathrm{~mm}$ is lower than 100 years.

Small changes in the SOC content (determined by oxidation with potassium dichromate in acid medium) in areas where biochar has been recently applied may be explained by the stability of pyrogenic carbon. According to Petter et al. (2012), the high molecular stability of pyrogenic carbon in biochar hinders the complete oxidation of the material derived from pyrolysis via this method.

\section{Production and nutrition of bean plant}

Grain dry mass (GDM) increased linearly with increasing concentrations of biochar from BRHF (Table 4). The addition of $10 \mathrm{~L} \mathrm{~m}^{-3}$ of this biochar led to an increase in GDM from $3.39 \mathrm{~g}$ (control treatment) to 18.73 g per plant. In the other experiments, the GDM values 
Table 4 - Regression equations adjusted between dry grain mass and biochar levels.

\begin{tabular}{lclccc}
\hline Variable response & Biochar & Equation & $\mathrm{R}^{2}$ & Vmax & Nmax \\
\hline \multirow{3}{*}{ DGM (g per plant) } & BRHF & $\mathrm{y}=21.412+11.539^{* *} \mathrm{x}-0.884^{*} \mathrm{x}^{2}$ & 0.94 & 18.73 & 10 \\
& $\mathrm{BSF}$ & $\mathrm{y}=65.201+28.598^{* *} \mathrm{x}-1.954^{*} \mathrm{x}^{2}$ & 0.97 & 17.57 & 6.80 \\
& $\mathrm{BSSF}$ & $\mathrm{y}=39.305+14.801^{* *} \mathrm{x}$ & 0.90 & 18.60 & 7.12 \\
\hline
\end{tabular}

$\overline{\mathrm{DGM}}=$ dry grain mass; Vmax $=$ maximum value of the variable response estimated by the regression equation; Nmax $=$ concentration of biochar corresponding to the maximum value of the variable response; $\mathrm{BRHF}=$ biochar from rice husk; BSF = biochar from sawdust filter; BSSF = biochar from sorghum silage filter.

changed quadratically with biochar concentrations (Table 4). In the experiment with BSF, the maximum GDM production was $17.57 \mathrm{~g}$ per plant at a concentration of 68 $\mathrm{L} \mathrm{m}^{-3}$ (Table 4), whereas in the experiment with BSSF, the maximum production was $18.60 \mathrm{~g}$ per plant at a concentration of $71 \mathrm{~L} \mathrm{~m}^{-3}$ (Table 4).

Uzoma et al. (2011) also observed positive effects on crop yield after biochar application and indicated that these effects are associated with the enhancement of soil chemical properties and increase in nutrient availability to plants.

Macronutrient in grain $(\mathrm{N}, \mathrm{P}, \mathrm{K}, \mathrm{Ca}, \mathrm{Mg}$, and $\mathrm{S})$ increased with biochar concentrations (Table 5), which indicated that biochar increases availability of nutrients to plants and/or enhances soil quality for crop growth. According to Chan et al. (2007), biochar addition promotes positive changes in soil quality, such as acidity correction, increased CEC, and improved environment for root growth. These effects promote greater nutrient use efficiency and absorption by plants.

In addition to the above-mentioned factors, although it was not within the scope of the present study, a higher number of nodules of nitrogen-fixing bacteria and greater number of fine roots were observed in the root system of plants that received biochar. Although long-term, open-field studies are still necessary, several authors have reported positive effects of biochar on nitrogen biological fixation (NBF). Rondon et al. (2007) showed that biochar addition to the soil increased availability of $\mathrm{B}, \mathrm{Mo}, \mathrm{K}, \mathrm{Ca}$, and $\mathrm{P}$, as well as soil $\mathrm{pH}$, thus favoring the increase in NBF. In addition, the ratio of $\mathrm{N}$ in bean plants via NBF increased from $50 \%$ to $72 \%$ with the incorporation of $90 \mathrm{~g} \mathrm{~kg}^{-1}$ of biochar.

In this study, the greatest $\mathrm{N}$ accumulation at higher biochar concentrations is probably also related to NBF (Table 5). Uzoma et al. (2011) indicated that biochar application to the soil is an alternative to improve the efficiency of nitrogenous fertilizers, especially in sandy soils, where $\mathrm{N}$ loss is a major agronomic and environmental problem.

The increase in grain phosphorus accumulation, which is the most limiting nutrient in the Brazilian Savanna soils, may be the result of plant-microorganism interactions, which may have contributed to $\mathrm{P}$ nutrition of the plants. Hammer et al. (2014) reported that biochar favors mycorrhizal associations and therefore the increase in P absorption. Lehmann et al. (2003) also observed an increase in $\mathrm{P}$ accumulation in the aerial part of caupi bean after biochar addition to the soil.
Table 5 - Regression equations adjusted between nutrient content in grains and biochar levels.

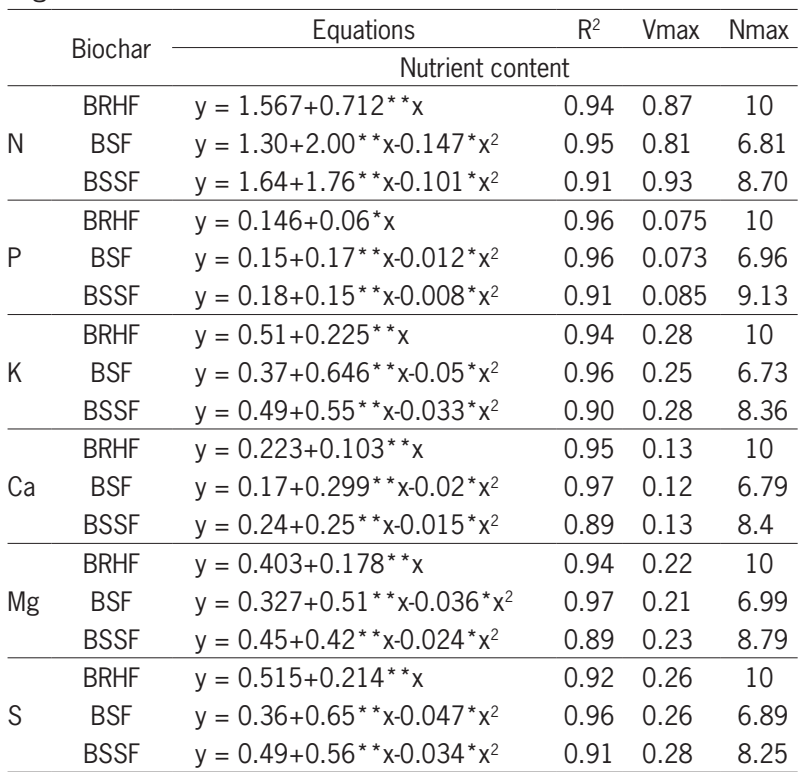

Vmax = maximum value of the variable response estimated by the regression equation; Nmax = concentration of biochar corresponding to the maximum value of the variable response; $\mathrm{BRHF}=$ biochar from rice husk; $\mathrm{BSF}=$ biochar from sawdust filter; BSSF = biochar from sorghum silage filter.

\section{Conclusion}

The three types of biochar improved the soil properties and increased the yield and accumulation of nutrients in the grains of the bean plant. The biochar from sorghum silage provided the best soil environment for the growth of bean plants.

The biochar concentrations corresponding to the maximum grain dry matter production were 100,68 and $71 \mathrm{~L} \mathrm{~m}^{-3}$ for biochar from rice husk filter (BRHF), sawdust filter (BSF), and sorghum silage filter (BSSF), respectively.

\section{Acknowledgements}

This research was supported by Research Division of the Federal University of Minas Gerais (PRPq/ UFMG) and funded by the Brazilian National Council for Scientific and Technological Development (CNPq) and by the Minas Gerais State Foundation for Research Support (FAPEMIG). 


\section{References}

Abdelhafez, A.A.; Li, J.; Abbas, M.H.H. 2014. Feasibility of biochar manufactured from organic wastes on the stabilization of heavy metals in a metal smelter contaminated soil. Chemosphere 117: 66-71.

Ahmad, M.; Rajapaksha, A.U.; Lim, J.E.; Zhang, M.; Bolan, N.; Mohan, D.; Vithanage, M.; Lee, S.S.; Ok, Y.S. 2014. Biochar as a sorbent for contaminant management in soil and water: a review. Chemosphere 99: 19-33.

Alburquerque, J.A.; Calero, J.M.; Barrón, V.; Torrent, J.; Campillo, M.C.; Gallardo, A.; Villar, R. 2014. Effects of biochars produced from different feedstocks on soil properties and sunflower growth. Journal of Plant Nutrition and Soil Science 177: 16-25.

Andrade, A.T.; Fernandes, L.A.; Faquin, V. 2002. Organic residue, limestone gypsum and phosphorus adsorption by lowland soils. Scientia Agricola 59: 349-355.

Bird, M.I.; Moyo, C.; Veenendaal, E.M.; Lloyd, J.; Frost, P. 1999. Stability of elemental carbon in savanna soil. Global Biogeochemical Cycles 13: 923-932.

Chan, K.Y.; van Zwieten, L.; Meszaros, I.; Downie, A.; Joseph, S. 2007. Agronomic values of green waste biochar as a soil amendment. Australian Journal of Soil Research 45: 629-634.

Cheng, C-H.; Lehmann, J.; Engelhard, M.H. 2008. Natural oxidation of black carbon in soils: changes in molecular form and surfasse charge along a climosequence. Geochimica et Cosmochimica Acta 72: 1598-1610.

Claessen, M.E.C. 1997. Methods of Soil Analysis Manual = Manual de Métodos de Análise de Solo. 2ed. Embrapa-CNPS, Rio de Janeiro, RJ, Brazil (in Portuguese).

Glaser, B.; Lehmann, J.; Zech, W. 2002. Ameliorating physical and chemical properties of highly weathered soils in the tropics with charcoal: a review. Biology Fertility of Soils 35: 219-230.

Hammer, E.C.; Balogh-Brunstad, Z.; Jakobsen, I.; Olsson, P.A.; Stipp, S.L.S.; Rillig, M.C. 2014. A mycorrhizal fungus grows on biochar and captures phosphorus from its surfaces. Soil Biology \& Biochemistry 77: 252-260.

Houben, D.; Evrard, L.; Sonnet, P. 2013. Beneficial effects of biochar application to contaminated soils on the bioavailability of $\mathrm{Cd}, \mathrm{Pb}$ and $\mathrm{Zn}$ and the biomass production of rapeseed (Brassica napus L.). Biomass and Bioenergy 57: 196-204.

Knicker, H. 2007. How does fire affect the nature and stability of soil organic nitrogen and carbon? A review. Biogeochemistry 85: 91-118.

Kookana, R.S.; Sarmah, A.K.; Zwieten, L.; van Krull, E.; Singh, B. 2011. Biochar application to soil: agronomic and environmental benefits and unintended consequences p. 103-143. In: Sparks, D.L., ed. Advances in agronomy. Academic Press, San Diego, CA, USA.
Lehmann, J.; Silva, J.P.; Steiner, C.; Nehls, T.; Zech, W.; Glaser, B. 2003. Nutrient availability and leaching in an archaeological Anthrosol and a Ferralsol of the Central Amazon basin: fertilizer, manure and charcoal amendments. Plant and Soil 249: 343-357.

Maathuis, F.J.M. 2013. Plant Mineral Nutrients: Method and Protocols. Humana Press, New Delhi, India.

Ministério da Agricultura, Pecuária e Abastecimento [MAPA]. 2015. Normative instruction SDA $n^{\circ}$ 03. Official Gazette - DOU of 26 Jan 2015 = Instrução Normativa SDA n ${ }^{\circ}$ 03. Diário Oficial - DOU de 27 de janeiro de 2015 Available at: http://extranet. agricultura.gov.br/sislegis-consulta/consultarLegislacao. do? operacao $=$ visualizar\&id $=3864[$ Accessed Feb 20, 2016 ] (in Portuguese).

Mukherjee, A.; Lal, R. 2016. Biochar and Soil Quality. CRC Press, Boca Raton, FL, USA.

Petter, F.A.; Madari, B.E.; Carneiro, M.A.C.; Marimon, B.H.; Carvalho, M.T.M.; Pacheco, L.P. 2012. Soil fertility and agronomic response of rice to biochar application in the Brazilian savannah. Pesquisa Agropecuária Brasileira 47: 699706.

Rondon, M.A.; Lehmann, J.; Ramirez, J.; Hurtado, M. 2007. Biological nitrogen fixation by common beans (Phaseolus vulgaris L.) increases with biochar additions. Biology and Fertility of Soils 43: 699-780.

Soil Survey Staff. 1998. Keys to Soil Taxonomy. 12ed. USDANatural Resources Conservation Service, Washington, DC, USA.

Steenari, B.M.; Karlsson, L.G.; Lindqvist, O. 1999. Evaluation of the leaching characteristics of wood ash and the infuence of ash agglomeration. Biomass and Bioenergy 16:119-136.

Troeh, F.R.; Thompson, L.M. 2005. Phosphorus. p. 342-371. In: Troeh, F.R.; Thompson, L.M., eds. Soils and soils fertility. Blackwell, New York, NY, USA.

Uzoma, K.C.; Inoue, M.; Andry, H.; Fujimaki, H.; Zahoor, A.; Nishihara, E. 2011. Effect of cow manure biochar on maize productivity under sandy soil condition. Soil Use and Management 27: 205-212.

Yuan, J.H.; Xu, R.K. 2012. Effects of biochars generated from crop residues on chemical properties of acid soils from tropical and subtropical China. Soil Research 50: 570-78. 